\title{
Nota sobre o apparelho de Baermann
}

\author{
por \\ Clemente Pereira \\ Trabalho do "Instituto Biologico"
}

7 ENDO escolhido um assumpto que fosse de alguma uti1 lidade para meus collegas, resolvi fazer uma descripção do apparelho de Baermann para o isolamento de larvas, que actualmente desempenha um relevante papel nas campanhas anti-helminthicas.

Como se sabe, a avaliação do grau de perigo que um sólo offerece sob o ponto de vista das helminthoses, tanto para o homem como para os animaes, era feita principalmente pelo grau de infestação helminthica do homem e dos animaes que o habitavam, sem que se possuisse, entretanto, um meio seguro para descobrir as verdadeiras fontes de infecção.

Bearmann, trabalhando nas Indias Hollandezas, em 1917, teve occasião de verificar que, porções de terra, contendo larvas de Ancylostoma duodenale e Necator americanus, postas em contacto com agua, atravez de uma tela de malhas finas, deixavam escapar para essa agua muitas das larvas que possuiam, podendo essas larvas ser recolhidas na agua.

Entretanto, esse autor não determinou as condições precisas de funccionamento do seu apparelho, e como sua publicação se fez em revista de difficil obtenção, por alguns annos permaneceu esse apparelho pouco conhecido.

Em 1921, quando os americanos atacavam decididamente o problema da opilação na America Central, tiveram occasião de experimentar o achado de Baermann, tendo então Cort, Ackert, Augustine e Payne traçado as normas de funccionamento efficiente desse apparelho, que passamos a resumir.

Nos nossos trabalhos, temos empregado um funil para filtração a quente (Fig. unica), que termina por um tubo 
de borracha (1), o qual possúe, proximo á extremidade livre, uma pinça de pressão constante (2). Colloca-se agua no espaço entre o revestimento de cobre e o funil de vidro (3). Enche-se de agua o funil de vidro até proximo do rebordo, e em seguida é essa agua aquecida por um bico de Bunsen (4) até cerca de 35 ou $400^{\circ}$ C., graduando-se o fogo para dar uma temperatura constante, dentro desses limites approximadamente.

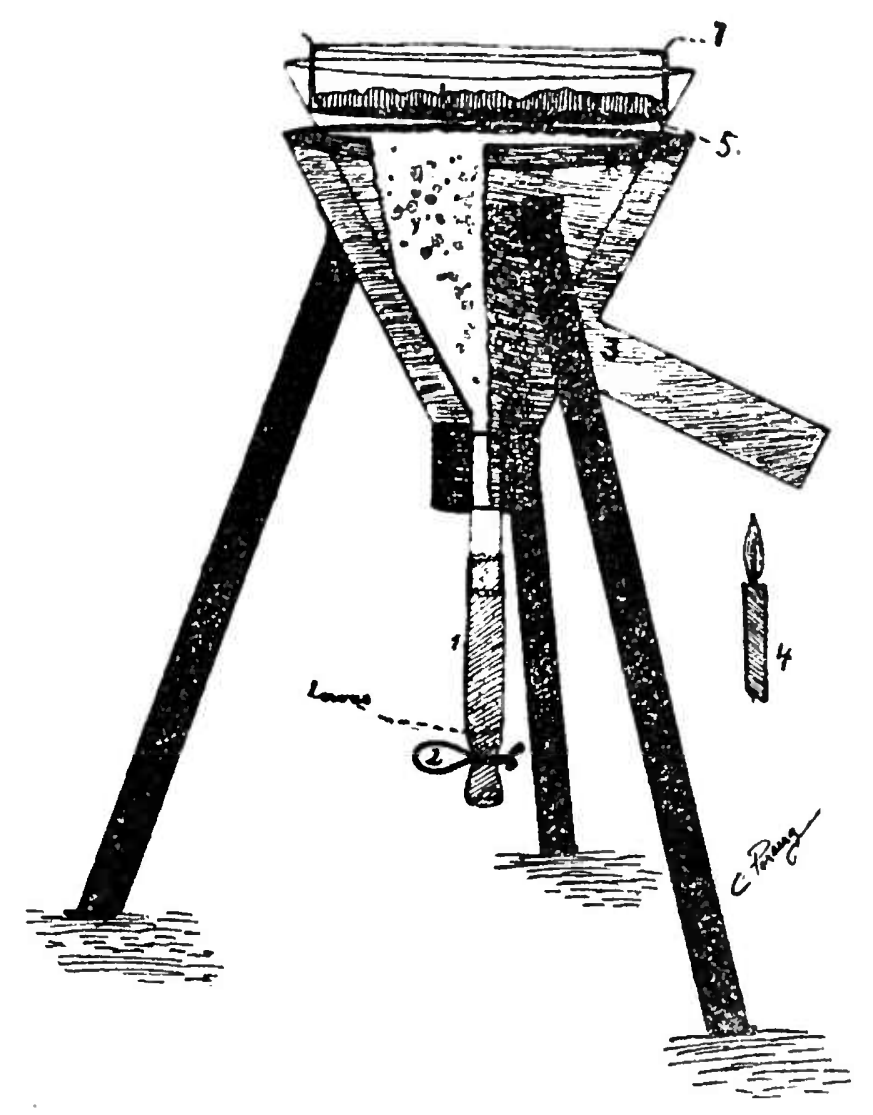

Em seguida colloca-se a terra a examinar (6) num tamiz de malhas de $1 \mathrm{~mm}$. (5), que deve apenas ser attingido pela agua do funil de vidro; como dessa maneira passa tambem terra, que irá prejudicar futuros exames microscopicos, os americanos aconselham a intercalação entre a terra e o tamiz, de um panno, que evitaria a passagem de terra; mas nós verificamos que, mesmo com essa precaução, ainda passavam particulas de terra. Pelo que, resolvemos substituir o panno por papel de filtro (7), obtendo os melhores resultados quanto ao rendimento de larvas, bem como impedindo completamente a passagem de terra.

Após 6 horas de funccionamento, obtem-se uma grande maioria das larvas existentes, restando no entanto uma pequena minoria que vae apparecendo depois; por isso é conveniente deixar o apparelho funccionando pelo espaço 
de uma noite, fazendo-se a colheita das larvas na manhã seguinte.

Para a obtenção das larvas que, pela acção da gravidade, estão reunidas no tubo de borracha, é sufficiente affrouxar a pinça de pressão constante do tubo de borracha e recolher a agua do funil de vidro num tubo de ensaio.

Vê-se, portanto, que o apparelho de Baermann constitue um processo muito elegante para o isolamento de larvas dos nematoides de penetração activa, localisadas no sólo, e, dessa maneira, revela com segurança os pontos de um terreno que constituem focos de infestação helminthica.

Feita uma cultura de nematoides monoxenos de penetração activa, póde essa cultura, depois de prompta, ser levada para o apparelho de Baermann, e assim serem as larvas obtidas com muita facilidade e limpeza.

Póde-se ainda, por meio desse apparelho, isolar do sólo nematoides de vida livre.

Quanto ao facto de as larvas se dirigirem para a agua aquecida, tudo leva a crer que o façam activamente, estimuladas pelo calor. 